conclusions, however brilliant, can have no value as guides to life or as guides to research, which is the second power of life. The theory of Monism has no interest to Science, until men can come to deal with the 'Stoff' on which its speculations rest. Every conceivable theory of life, its nature, origin and destiny, can be traced back to the pre-scientific philosophy of the Ancients, Monism with the rest. What we have found to be true was not unknown to the Greeks. But that which we find to be false had equally the weight of their authority. It is the business of Science to test by its own methods the value of the supposed basis of these theories. The use of logic is one of these methods. The only logical necessity Science can recognize, as Dr. Brooks has well said, is "that when our knowledge ends we should confess our ignorance."

I have myself not the slightest objection to 'Monism' as philosophy. . As a dogma it is certainly more attractive than many others which have been brought like lightning from the clouds, as a stimulus to creeping humanity. My objection lies against the use of the divining rod in connection with the microscope. These instruments do not yield homologous results. If both yield Truth, then Truth is a word of double meaning. This method seems to carry us back to the days when truths were made known to the spirit without the intervention of the body. When some theologian of the past brought to Luther the revelations his spirit made to him, the sturdy Reformer said, "Ihren Geist haue ich über die Schnautze" (I slap your spirit on the snout). Scientific men may have as individuals their own visions and guesses and formulæ of Universal Philosophy. Spiritual gymnastics are not without value to any worker, and men of science have often suffered from their neglect. But this suffering is purely individual. The running high jump does not hasten the progress of knowledge. Science will have none of it. Nor will she tolerate a divining rod even in the hands of her wisest devotees. In other words, where the facts stop Science stops also.

David Stakr JoRdAN.

STANFORD UNIVERSITY.

THE GENUS Zaglossus.

To the Editor of Scrence: Mr. T. S. Palmer's article in Science of May 10th fixes the synonymy of this genus with precision; but one statement he makes is incorrect, namely, that ' Zaglossus Gill seems never to have been mentioned by any subsequent author.' The Century Dictionary has three articles from my pen on the subject. 1. Zaglossus is defined as ' the proper name of that genus of prickly ant-eaters which is better known by its synonym Acanthoglossus (which see).' 2. Under Acanthoglossus the genus is characterized, with the statement that this name 'is antedated by 'Zaglossus of Gill.' 3. Under Echidnidae the animal is figured with the legend 'Zaglossus or Acanthoglossus bruijni.'

Elliott Coues.

\section{SCIENTIFIC LITERATURE.}

The Cambridge Natural History, III., Molluscs :

By the Rev: A. H. Cook ; Brachiopods (Recent) : By A. E. ShIpley ; Brachiopods (Fossil): By F. R. C. Reed. New York, Macmillan \& Co. 1895. XIV., 536. Pp. $8^{\circ}$. Illustrated.

This work is one of a series intended esंpecially for intelligent persons without scientific training, but in which the attempt is made to combine popular treatment and untechnical language with the latest results of scientific research.

Mr. Cooke, who is known as a painstaking and well informed conchologist, has endeavored to unite in one general classification the views of specialists in the various groups, such as Hoyle for the recent, Foord and Fischer for the fossil Cephalopods, Bergh for the Nudibranches, Pelseneer for the Pelecypoda, etc.; but, in conformity with 